\title{
Adenosine Deaminase Activity and Free IL-2 Receptor Levels in Serum from Patients with Mycoplasma Pneumonia
}

\author{
Moritaka SUGA*,**, Masayuki ANDO*, Hiroshi NISHIKAWA*** and Shukuro ARAKI*
}

\begin{abstract}
Adenosine deaminase (ADA) activity and free interleukin (IL)-2 receptor levels were assayed in serum samples from patients with mycoplasma and bacterial pneumonia to evaluate the usefulness of these parameters in distinguishing between these diseases at an early stage. Serum ADA and free IL-2 receptor levels in patients with mycoplasma pneumonia $(32.4 \pm 9.2 \mathrm{U} / 1,960 \pm 204 \mathrm{U} / \mathrm{ml})$ were significantly higher than those in patients with bacterial pneumonia $(12.5 \pm 3.3 \mathrm{U} / \mathrm{l}, 425 \pm 86 \mathrm{U} / \mathrm{ml})$ and in healthy controls $(14.0 \pm 3.4 \mathrm{U} / \mathrm{l}, 286 \pm 49$ $\mathrm{U} / \mathrm{ml})(\mathrm{p}<0.001)$. Of the 20 mycoplasma pneumonia cases, 19 showed increased levels of ADA over 20.8 $\mathrm{U} / \mathrm{l}$; in 17 of the 19, the increase of ADA was seen before the elevation of the specific antibody to Mycoplasma pneumoniae. In contrast, serum ADA levels in all 20 cases of bacterial pneumonia were lower than $20.8 \mathrm{U} / \mathrm{I}$. These results indicate that assays for serum ADA and free IL-2 receptor levels are useful in distinguishing between bacterial and mycoplasma pneumonia at an early stage.
\end{abstract}

Key words: Pneumonia, ADA, T cell activation

Unlike bacterial pneumonia, the pathogenesis of mycoplasma pneumonia is thought to involve immune mechanisms, particularly $\mathrm{T}$ cells $(1-4)$. Adenosine deaminase (ADA) activity is high in lymphoid tissue, particularly precursor $\mathrm{T}$ lymphocytes (5), and higher in peripheral $\mathrm{T}$ cells than in $\mathrm{B}$ cells (6). ADA is thought to be required for induction of $T$ cell (7) and monocyte (8) differentiation. Clinically, an elevation of ADA activity in serum and thoracic fluid has been found in diseases involving cell-mediated immunity (9-12). The expression of the interleukin (IL)-2 receptor occurs when $\mathrm{T}$ cells are activated by stimulants such as mitogen or antigen (13). Free IL-2 receptor in the serum is a sensitive index of the IL-2 receptor status (14-16) and its elevation in adult $\mathrm{T}$ cell leukemia reflects increased levels of activated, proliferating $T$ cells (17).

In cases of acute pneumonia, determination of the pathogen directly affects the therapeutic regimen. During the early stages, the pathogen for acute pneumonia is speculated from symptoms, leukocyte count, and chest X-ray findings. Mycoplasma pneumonia is characterized by an intense, dry cough present from the onset, interstitial shadow on chest $\mathrm{X}$-ray films, and the absence of leukocytosis. It is frequently treated with tetracycline or macrolide antibiotics. In some cases, however, beta-lactam antibiotics, ineffective in this type of pneumonia, are used at the early stage based on a suspicion of bacterial pneumonia. In addition, there are cases where a diagnosis of mycoplasma pneumonia is made based on the finding of an elevated specific antibody to Mycoplasma pneumoniae during patient follow-up. The distinction between mycoplasma and bacterial pneumonia has been frequently difficult at an early stage before elevation of specific antibody

From *The First Department of Internal Medicine, Kumamoto University Medical School, Kumamoto, **Kumamoto Rosai Hospital, Yatsushiro and ***Self Defense Force Kumamoto Hospital, Kumamoto Received for publication October 2, 1989; Accepted for publication October 25, 1990 Reprint requests should be addressed to Moritaka Suga, MD, The First Department of Internal Medicine, Kumamoto University Medical School, 1-1-1 Honjo, Kumamoto 860, Japan 
to $M$. pneumoniae, and no effective auxiliary diagnostic tool has been available. If a distinction between mycoplasma and bacterial pneumonia is possible at an early stage, more appropriate treatment can be applied.

Therefore, serum ADA activity and free IL-2 receptor levels were assayed in pneumonia patients to elucidate the differences in immunological responses between mycoplasma and bacterial pneumonia and to assess the usefulness of these parameters for early diagnosis.

\section{SUBJECTS AND METHODS}

\section{Subjects}

Included were 40 cases of pneumonia, without underlying diseases, who visited our department or related institutions within 10 days after onset and who were subsequently treated as inpatients from July 1984 to January 1989 . There were 20 cases of mycoplasma pneumonia (15 males and 5 females), with ages ranging from 20 to 43 yr (mean: 33.4 $\mathrm{yr}$ ), and 20 cases of bacterial pneumonia (16 males and 4 females), with ages ranging from 18 to 48 yr (mean: 33.9 yr). Thirty healthy volunteers (15 males and 15 females), with ages ranging from 22 to $53 \mathrm{yr}$ (mean: $38.6 \mathrm{yr}$ ), served as controls.

\section{Onset and diagnosis of pneumonia}

The day when symptoms of respiratory infection, such as fever and cough, appeared was regarded as the day of disease onset.

A diagnosis of mycoplasma pneumonia was made when the antibody titer to Mycoplasma pneumoniae in a single serum sample was elevated to 64-fold or more by the complement fixation test or to 320-fold or more by the indirect hemagglutination test, or when the titer in paired serum samples showed a 4-fold or more increase. In 20 cases diagnosed as having bacterial pneumonia, antibody titer to $M$. pneumoniae and cold agglutination showed no elevation, leukocytosis was present, and a significant pathogen was found in the sputum. All cases of bacterial pneumonia responded to therapy with beta-lactam antibiotics. Cases of atypical pneumonia, which showed a clinical course similar to mycoplasma pneumonia but also showed an elevated cold agglutination and no elevation of antibody to $M$. pneumoniae, were excluded from this study.

\section{Extent of infiltrates on chest $X$-ray films}

The extent of infiltrates on chest X-ray films, which were taken at the first measurement of ADA, were classified on a four-grade scale: score 0 , no shadow; score 1, a focal shadow not exceeding one intercostal space; score 3, a shadow covering one lobe or more; score 2, a shadow area between scores 1 and 3.

Assay for $A D A$

ADA was determined according to the method of Guisti (18). Serum $(0.05 \mathrm{ml})$ was incubated for $60 \mathrm{~min}$ at $37^{\circ} \mathrm{C}$ in $1.0 \mathrm{ml}$ of buffered adenosine solution ( $21 \mathrm{mM}$ adenosine and $50 \mathrm{mM}$ phosphate). Then $3.0 \mathrm{ml}$ of phenol-nitroprussid solution (106 $\mathrm{mM}$ phenol and $0.17 \mathrm{mM}$ sodium nitroprussid) and $3.0 \mathrm{ml}$ of alkaline hypochlorite solution $(11 \mathrm{mM}$ $\mathrm{NaOCl}$ and $125 \mathrm{mM} \mathrm{NaOH}$ ) were added. The solution was incubated for $30 \mathrm{~min}$ at $37^{\circ} \mathrm{C}$, and then was measured with a spectrometer at $626 \mathrm{~nm}$.

$\frac{\text { sample-sample blank }}{\text { standard-reagent blank }}=$ ADA activity $\mathrm{U} / 1\left(37^{\circ} \mathrm{C}\right)$

Assay for free IL-2 receptor

Free IL-2 receptor was determined by ELISA using a cell free IL-2 receptor kit (T-cell Sciences, MA).

Statistical analysis

Values were expressed as mean \pm SD. Statistical significance of differences was tested by the Student's t-test with $\mathrm{p}<0.05$ regarded as significant.

\section{RESULTS}

The interval from disease onset to the first examination of serum ADA was within 10 days in all cases and did not significantly differ between mycoplasma pneumonia ( $6 \pm 2.5$ days) and bacterial pneumonia (4.6 \pm 2.3 days). There was no significant difference in age among the cases of mycoplasma pneumonia $(30.0 \pm 6.5 \mathrm{yr})$, bacterial pneumonia $(33.9 \pm 12.5)$ and healthy controls (38.6 \pm 11.5$)$.

Serum ADA in patients with mycoplasma pneumonia was $32.4 \pm 9.2 \mathrm{U} / 1(63.9-18.7 \mathrm{U} / 1)$, while in patients with bacterial pneumonia and in healthy controls it was $12.5 \pm 3.3(4.6-18.6 \mathrm{U} / \mathrm{l})$ and $14.0 \pm 3.4 \mathrm{U} / 1(6.3-19.3 \mathrm{U} / \mathrm{l})$, respectively. ADA in patients with mycoplasma pneumonia was significantly higher than in patients with bacterial 


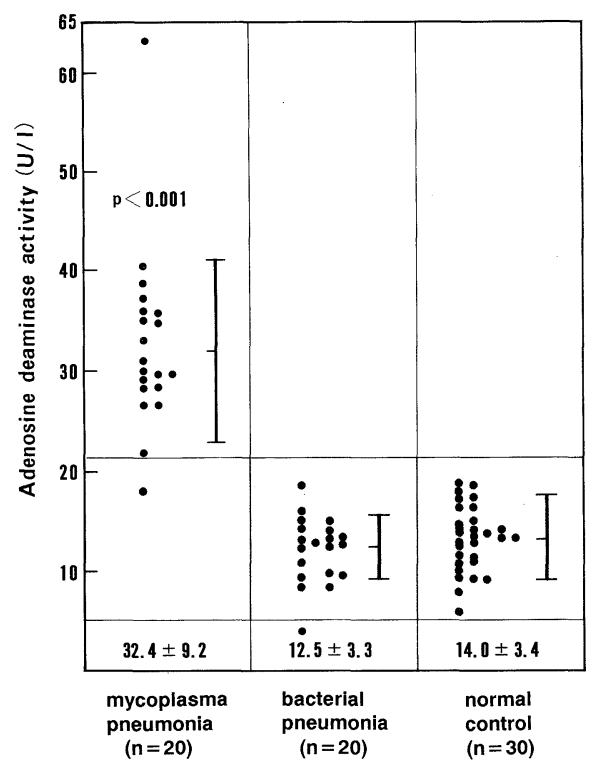

Fig. 1. Serum adenosine deaminase (ADA) activity in patients with mycoplasma and bacterial pneumonia.

pneumonia and healthy controls ( $p<0.001$, Fig. 1). In 19 of the 20 cases of mycoplasma pneumonia, serum ADA exceeded $20.8 \mathrm{U} / \mathrm{l}$, which was the mean activity of the healthy controls $+2 \mathrm{SD}$. On the other hand, none of the 20 cases of bacterial pneumonia exceeded $20.8 \mathrm{U} / 1$.

In the relationship between ADA activity and the extent of infiltrates on chest X-ray films in patients with mycoplasma pneumonia, the cases with a score of 3 tended to show a higher ADA activity $(42.8 \pm 15.5 \mathrm{U} / \mathrm{l} ; \mathrm{n}=3)$ than the score 2 cases $(30.6 \pm 6.9 \mathrm{U} / \mathrm{l} ; \mathrm{n}=12)$ or score $1(30.9 \pm 6.0 \mathrm{U} / \mathrm{l}$; $\mathrm{n}=5$ ), though there was no correlation between the ADA activity and the extent of infiltrates (Fig. 2).

In patients with mycoplasma pneumonia, ADA activity did not correlate with the interval from disease onset to the first ADA examination (3-10 days), with the antibody titer to $M$. pneumoniae, leukocyte count, peripheral lymphocyte count, $\mathrm{C}$-reactive protein, or cold agglutination (data not shown). In 17 of 20 cases of mycoplasma pneumonia, antibody to $M$. pneumoniae was negative in the early stage between 3 and 10 days after disease onset, while serum ADA was elevated.

In five healthy controls in which the free IL-2

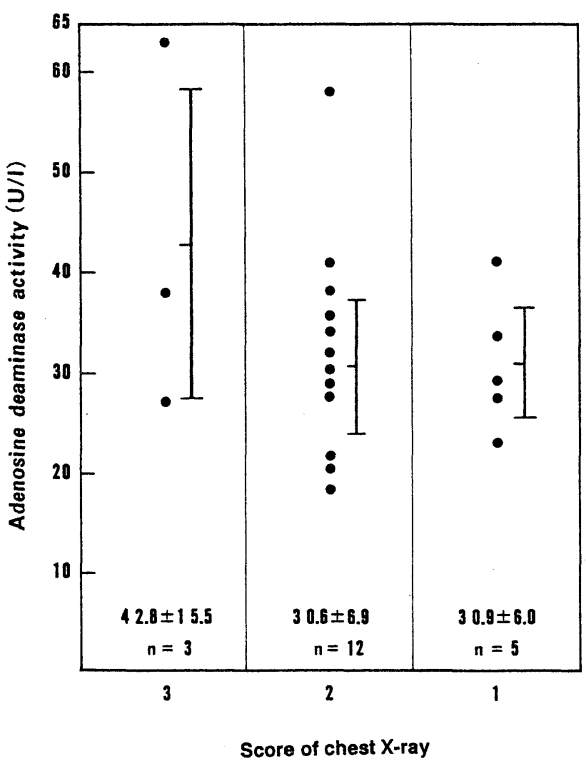

Fig. 2. Relationship between adenosine deaminase (ADA) activity and the extent of chest $\mathrm{X}$-ray shadow. Score: 1 , a focal shadow which does not exceed one intercostal space; 2 , area between 1 and 3 ; 3, a shadow covering one lobe or more.

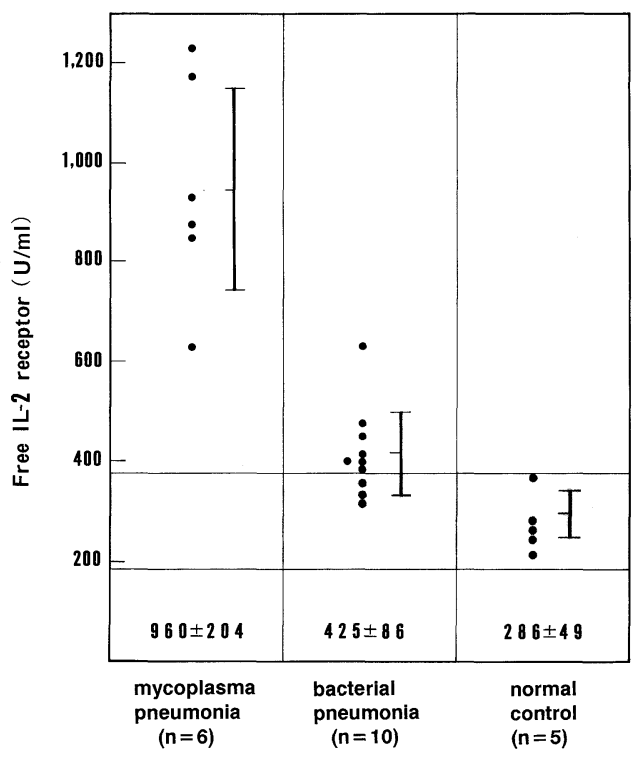

Fig. 3. Free IL-2 receptor level in serum of patients with mycoplasma and bacterial pneumonia. 
receptor level in the serum was determined, the mean was $286 \pm 49 \mathrm{U} / \mathrm{ml}$. For ten cases of bacterial pneumonia, the mean free IL-2 receptor level was somewhat higher $(425 \pm 86 \mathrm{U} / \mathrm{ml} ; 325-644 \mathrm{U} / \mathrm{ml})$, although the difference was not statistically significant. The free IL-2 receptor values for six cases of mycoplasma pneumonia $(960 \pm 250 \mathrm{U} / \mathrm{ml}$; $637-1,240 \mathrm{U} / \mathrm{ml}$ ) were significantly higher than in healthy controls and cases of bacterial pneumonia ( $<<0.001$, Fig. 3).

\section{DISCUSSION}

The present study showed that the level of serum ADA and free IL-2 receptor in patients with mycoplasma pneumonia was significantly higher than in patients with bacterial pneumonia and in healthy controls, and that the elevation of ADA in mycoplasma pneumonia occurs in the early stage before the elevation of the specific antibody to $M$. pneumoniae. These results indicate that the immunological responses to mycoplasma and bacterial pneumonia differ, and that the assay of ADA and free IL-2 receptor in the serum is useful for early diagnosis of mycoplasma pneumonia.

It has been demonstrated both experimentally and clinically that humoral immunity and cellmediated immunity are established following mycoplasma infection (1-4). Mycoplasma-related factors known to induce pneumonia include toxin of mycoplasma, tissue injury due to nonspecific inflammatory reaction, and lung injury due to an immune mechanism mediated by $T$ cells. Lymphocyte infiltration and activation, particularly of $\mathrm{T}$ cells, has been found in inflamed regions of the lung (19). Severe mycoplasma pneumonia has been attributed to temporary regional immunological hypersensitivity of the lungs (20). The present study with ADA and free IL-2 receptors, which are indicators of $\mathrm{T}$ cell activation, also supports the concept that $\mathrm{T}$ cell activation occurs in patients with mycoplasma pneumonia.

Perhaps the most interesting finding was that serum ADA in patients with mycoplasma pneumonia was increased at the early stage between the $3 \mathrm{rd}$ and 10th day after disease onset, i.e., before elevation of specific antibody to M. pneumoniae. This result indicates that ADA is a very useful parameter for distinguishing between mycoplasma and bacterial pneumonia at the early stage.

ADA activity in patients with non-bacterial pneumonia other than mycoplasma pneumonia is unknown. However, considering the mechanism of ADA elevation, it seems likely that viral pneumonia also shows ADA elevation. In two of three patients with atypical pneumonia showing elevated cold agglutination and negative mycoplasma antibody. ADA was also high (data not shown). In patients with pulmonary tuberculosis, serum ADA activity has been reported to be generally high, although it varies greatly among individuals. Therefore, if the diagnosis of mycoplasma pneumonia at the early stage of pneumonia is based on serum ADA levels, care is needed to distinguish mycoplasma pneumonia from atypical pneumonia and pulmonary tuberculosis. However, the distinction between pulmonary tuberculosis and acute pneumonia is relatively simple, and many cases of atypical pneumonia respond to tetracyclines or macrolides, as does mycoplasma pneumonia. So, also from the viewpoint of treating pneumonia at its early stage, the assay for serum ADA is quite significant. In one case of mycoplasma pneumonia, ADA activity did not exceed the mean \pm 2 SD of healthy controls. In this case, ADA on the fifth day after onset was $18.7 \mathrm{U} / 1$, chest X-ray shadow was rated as score 2, leukocytosis was absent, and treatment with beta-lactam was ineffective, but treatment with clindermycin and erythromycin was effective. Antibodies to $M$. pneumoniae showed a 4 -fold increase in paired serum samples, but cold agglutination was low. Clinically, this case did not differ from the other cases of mycoplasma pneumonia except that the ADA activity on the fifth day after onset and cold agglutination were low. The reason for the low ADA activity in this case was not determined. From the third to tenth day after disease onset, no correlation was found between the interval from onset to the first ADA assay and the ADA activity. Serum ADA is known to rise following hepatic impairment (21). However, when liver function was examined in 12 of 20 patients with mycoplasma pneumonia, no abnormality indicative of hepatic impairment was found. Changes in ADA activity throughout the course of mycoplasma pneumonia and after its cure need further investigation.

In patients with mycoplasma pneumonia, ADA 
activity did not consistently correlate with the extent of infiltrates on chest X-ray, although ADA activity tended to be high in cases showing a shadow exceeding one lobe. Even though the number of cases examined was too small to allow for sufficient statistical analysis, it seems unlikely, judging from the leukocyte count and sputum culture, that secondary bacterial infection (sometimes seen during mycoplasma pneumonia) affected chest X-ray findings. If ADA correlates with $\mathrm{T}$ cell activation, the above-mentioned chest X-ray findings may be explained by the fact that regional immune responses are not always reflected in peripheral blood, that there is a time lag between the peak of immunological response and the peak of chest X-ray shadow, or that factors other than immunological mechanisms may be involved in the regional inflammatory reaction. In the present study, the reason remains obscure.

\section{REFERENCES}

1) Denny FW, Taylor-Robinson D, Allison AC. The role of thymus-dependent immunity in Mycoplasma pneumoniae infections of mice. J Med Microbiol 5: 327, 1972.

2) Taylor G, Taylor-Robinson D, Fernald GW. Reduction in the severity of Mycoplasma pneumoniae-induced pneumonia in hamsters by immunosuppressive treatment with antithymocyte sera. J Med Microbiol 7: 343, 1974.

3) Biberfeld G, Sterner G. Effect of Mycoplasma pneumoniae infection on cell-mediated immunity. Infection 4: s17, 1976.

4) Fernald GW. Pathogenecity of mycoplasmas for man, animals, plants and insects. Zbl Bakt Hyg I Abt Orig A 245: 139, 1979.

5) Barton R, Martiniuk F, Hirschhorn R, Goldschneider I. The distribution of adenosine deaminase among lymphocyte population in the rat. J Immunol 122: 216, 1979.

6) Macdermott RP, Tritsch GL, Formeister JF. Adenosine deaminase and nucleotide phosphorylase activities in normal human blood mononuclear cell subpopulations. Clin Exp Immunol 42: 303, 1980.

7) Ballet JJ, Insel $R$, Merler E, Rosen FS. Inhibition of maturation of human precursor lymphocytes by coformycin, an inhibitor of the enzyme adenosine deaminase. J Exp Med 143: 1271, 1976.

8) Fischer D, Weyden MB, Snyderman R, Kelley WN. A role for adenosine deaminase in human monocyte maturation. J Clin Invest 58: 399, 1976.

9) Ocana I, Martinez-Vazquez JM, Segura RM, Fernandez-De-Sevilla T, Capdevila JA. Adenosine deaminase in pleural fluids: Test for diagnosis of tuberculous pleural effusion. Chest 84: 51, 1983.

10) Nishikawa H, Suga $M$, Sugimoto $M$, Fukushima $K$, Ando M, Araki S. Clinical significance of measurement of adenosine deaminase activity in pleural effusion for differential diagnosis of pleuritis: Influence of the hemolysis in pleural effusion on ADA activity. Jpn J Thorac Dis 24: 230, 1986 (in Japanese).

11) Galanti B, Nardiello S, Russo M, Fiorentino F. Increased lymphocyte adenosine deaminase in typhoid fever. Scand Infect Dis 13: 47, 1981.

12) Paras MA, Gakis C, Brudoni M, Andreoni G. Immunological studies in Mediterranean spotted fever. Lancet 1 (82839): 1249, 1982.

13) Uchiyama T, Border TS, Waldman TA. A monoclonal antibody (anti-Tac) reactive with activated and functionally mature human T cells. I. Production of antiTac monoclonal antibody and distribution of Tac (+) cells. J Immunol 126: 1393, 1981.

14) Rubin LA, Kurman CC, Fritz ME, Biddeson WE, Boutin B, Yarchoan R, Nelson DL. Soluble interleukin-2 receptors are released from activated human lymphoid cells in vitro. J Immunol 135: 3172, 1985.

15) Nelson DL, Rubin LA, Kurman CC, Fritz ME, Boutin B. An analysis of the cellular requirements for the production of soluble interleukin-2 receptors in vitro. J Clin Immunol 6: 114, 1986.

16) Teshigawara $\mathrm{K}$, Wang $\mathrm{H}$, Kato $\mathrm{K}$, Smith KA. Interleukin 2 high-affinity receptor expression requires two distinct binding proteins. J Exp Med 165: 223, 1987.

17) Nelson DL. Expression of a soluble form of the interleukin-2 receptor in normal and neoplastic states. The human interleukin-2 receptor: Normal and abnormal expression in $\mathrm{T}$ cells and in leukemias induced by the human T-lymphotropic viruses. Greene WC, moderator. Ann Intern Med 105: 560, 1986.

18) Guisti G. Adenosine deaminase. in: Methods of Enzymatic Analysis, Bergmeyer HU, Ed. Academic Press, New York, 2nd ed, 1974, p.1092.

19) Hayashi S, Ichikawa $Y$, Fujino K, et al. Analysis of lymphocyte subsets in peripheral blood and bronchoalveolar lavage fluid in patients with pneumonia due to Mycoplasma pneumoniae. Jpn J Thorac Dis 24: 162, 1985 (in Japanese).

20) Terada $Y$, Matsunobe S, Muro K, Go T, Chihara K, Tonomura S, Shimizu Y. Effects of hydrocortisone in severe Mycoplasma pneumoniae pneumonia. Jpn J Thorac Dis 25: 203, 1987 (in Japanese).

21) Kohler LH, Berz EJ. Serum adenosine deaminase: Methodology and clinical application. Clin Chem 8: 133, 1962. 